\title{
Quantitative Assessment of Parkinson's Disease Using Gait Analysis
}

○岡本 剛（九大） 正 中西 義孝（九大）飛松 省三 （九大）牧之内 顕文（久工大） Tsuyoshi OKAMOTO, Yoshitaka NAKANISHI, Shozo TOBIMATSU,

Kyushu University, 3-1-1 Maidashi, Higashi-ku, Fukuoka Akifumi MAKINOUCHI, Kurume Institute of Technology

Key Words : Parkinson's Disease, Gait Analysis, Foot Pressure, Clinical Stratification

\section{1. はじめに}

パーキンソン病 (Parkinson's Disease, PD) は，神経内 科疾患のうち脳血管障害の次に発症数が多い難病である. わが国での患者数は 7 万人を超え, 65 歳以上では人口 10 万人あたりの患者数が 100 150人にも達する.PDの克服 は社会的な課題の一つとなっているが，PD は脳機能画像 では通常診断できず，初期には三主徵 (振戦、筋固縮、無 動)が全て表れないため，專門医にも早期の診断は難しい， 従来, PD の重症度はホーエン・ヤールの重症度分類 ${ }^{(1)}$ あるいは統一 PD 評価スケール (Unified Parkinson Disease Rating Scale, UPDRS) (2)を用いて分類されてきた。 ホーエン・ヤールの重症度分類 (表 1) では詳細に症状を表 すことはできない，UPDRS は全 42 項目を各 5 段階の点数 で評価するため定量的に評価することはできるが，評価 には相応の時間がかかる. 何れの評価法においても医師 および患者の主観が入り込むことに起因する曖昧さは排 除できない，そこで本研究では非侵襲で低負担な歩行計 測を行い，計測データを解析することで定量的かつ客観 的に PD の重症度が評価できる新たな指標を作成すること を目的とする。

\section{2. 方法}

\section{1 歩行計測}

本研究では足圧分布測定装置( ニッタ株式会社 BIGMAT $1300 ， 440 \mathrm{~mm} \times 480 \mathrm{~mm}, 8$ 枚使用), 筋電計 (キッセイコ ムテック社 VitalRecorder)およびアクティブ赤外線方 式モーションキャプチャーシステム (ASCENSION 社 ReActor)を同期させた歩行計測システムを構筑し, 被験者 (健常者 4 名, PD 患者 4 名; 表 2)の歩行データを計測した（図 1).1 回の計測に際し, 被験者には計測装置をつけたまま足 圧計上の約 $4 \mathrm{~m}$ を往復してもらい, 随意歩行およびメトロノー ムによるテンポ指定歩行 (1 分間に 90 拍)をそれぞれ 3 回ずつ 計測した.

\section{2 歩行解析}

本研究では，2.1 で述べた歩行計測システムのうち足圧分 布データの解析を行い, PD の歩行障害を定量化する指標の作 成を行った. 1 回の歩行計測における足圧分布データは 384 $\times 44$ (pixel) $\times$ frame 数 (時閒解像度は $60 \mathrm{fps}$ )の行列から なる。具体的な解析手順を以下に示す。

まず, 位置 $(i, j)$, 時刻 $t$ における圧力值 $p(i, j, t)$ を片足 ごとに分離した。

$$
p_{\mathrm{F}}(i, j, t)= \begin{cases}p(i, j, t), & p(i, j, t) \in F(t), \\ 0, & \text { otherwise. }\end{cases}
$$

ここで $L(t)$ または $R(\mathrm{t})(F=L, R)$ は, 時刻 $t$ における左右それぞ れの足に由来する圧力値の集合を表す. 次に, 各時刻, 各足 の圧力中心ベクトル $\boldsymbol{g}_{\mathrm{F}}(t)$ を以下のように求めた.

$$
\begin{aligned}
\boldsymbol{g}_{\mathrm{F}}(t) & =\frac{1}{P(t)} \sum_{i} \sum_{j} p_{\mathrm{F}}(i, j, t) \cdot\left(\begin{array}{ll}
i & j
\end{array}\right)^{T}, \\
P(t) & =\sum_{i} \sum_{j} p_{\mathrm{F}}(i, j, t) .
\end{aligned}
$$

Table 1 Hoehn and Yahr Staging of Parkinson's Disease

\begin{tabular}{|c|l|}
\hline$I$ & 症状が片方の手足のみ \\
\hline II & 症状が両方の手足にみられる \\
\hline III & $\begin{array}{l}\text { 姿勢反射や歩行の障害 (小刻みな歩行, ゆっく } \\
\text { りとした動作) が加わる }\end{array}$ \\
\hline IV & $\begin{array}{l}\text { 起立, 歩行は可能だが, 非常に不安定で介助が } \\
\text { 必要 }\end{array}$ \\
\hline V & 車椅子使用か, ほとんど懮たきり \\
\hline
\end{tabular}

Table 2 Profiles of the subjects

(N: normal, PD: PD patient, M: male, F: female)

\begin{tabular}{|c|c|c|c|c|c|c|c|c|}
\hline Model & B & C & D & E & F & G & H & I \\
\hline State & N & N & PD & PD & N & PD & N & PD \\
\hline Height & 157 & 171 & 151 & 157 & 175 & 168 & 171 & 154 \\
\hline Age & 24 & 21 & 75 & 83 & 33 & 75 & 24 & 64 \\
\hline Sex & M & M & F & M & M & M & M & F \\
\hline
\end{tabular}

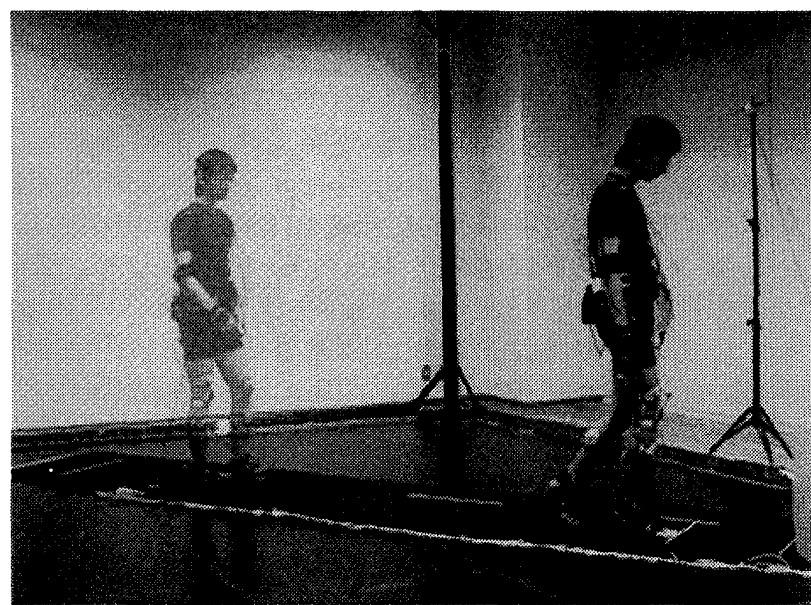

Figure 1 Experimental procedures.

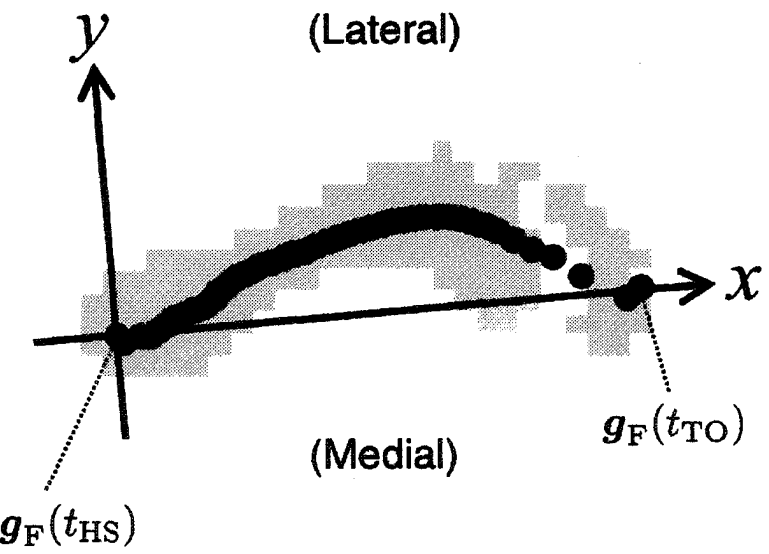

Figure 2 Definition of coordinate axes. 
ただし式(2)右肩の $T$ は転置記号である (以下同じ).さらに, 踵接地時刻 $t_{\mathrm{HS}}$ の圧力中心座標 $\boldsymbol{g}_{\mathrm{F}}\left(t_{\mathrm{HS}}\right)$ を原点とし, 原点から 爪先離地時刻 $t_{\mathrm{TO}}$ の圧力中心座標 $\boldsymbol{g}_{\mathrm{F}}\left(t_{\mathrm{TO}}\right)$ に向かって $x$ 軸を, 原点から体の外側に向かって $x$ 軸と直交するように $y$ 軸を それぞれ取るように座標変換を行い，足圧データを基準 化した (図 2).

$$
\begin{aligned}
& \boldsymbol{h}_{\mathrm{F}}(t)=\frac{R\left[\boldsymbol{g}_{\mathrm{F}}(t)-\boldsymbol{g}_{\mathrm{F}}\left(t_{\mathrm{HS}}\right)\right]}{\left\|\boldsymbol{g}_{\mathrm{F}}\left(t_{\mathrm{TO}}\right)-\boldsymbol{g}_{\mathrm{F}}\left(t_{\mathrm{HS}}\right)\right\|}, \\
& R=\left(\begin{array}{cc}
\cos \theta & -\sin \theta \\
\sin \theta & \cos \theta
\end{array}\right) \text {, } \\
& \theta=-\arctan \left(\frac{g_{\mathrm{F} y}\left(t_{\mathrm{TO}}\right)-g_{\mathrm{F} y}\left(t_{\mathrm{HS}}\right)}{g_{\mathrm{F} x}\left(t_{\mathrm{TO}}\right)-g_{\mathrm{F} x}\left(t_{\mathrm{HS}}\right)}\right),
\end{aligned}
$$

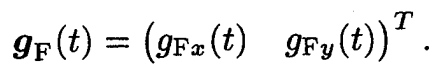

\section{3. 結果}

2.2 のデータ解析方法に基づき, 各試行 (1 往復)のうち往路 の最初 4 歩分および復路の最初 4 歩分の圧力中心軌跡を計算 した. 歩行計測一試行 (8 歩分) の圧力中心軌跡について, 健 常者およびPD 患者の典型例を図 3 に示す.この結果より, 健 常者は歩行時足圧の圧力中心軌跡が単峰型で, 足裏の中心と 爪先との䦓にピークを持つように体の外側に向けて膨らむの に対し，PD患者はピークの数も位置も不規則な傾向を示すこ とがわかった。

次に，この傾向を歩行指数として定量化するために，踵接 地から爪先離地の中間領域における圧力中心軌跡の平均値を 以下のように計算した.

$$
\begin{aligned}
& \text { Gait Index }=\frac{1}{N(\tau)} \sum_{t \in \tau} h_{\mathrm{F} y}(t), \\
& h_{\mathrm{F}}(t)=\left(h_{\mathrm{F} x}(t) \quad h_{\mathrm{F} y}(t)\right)^{T}, \\
& \tau=\left\{t \mid 0.25 \leq h_{\mathrm{F} x}(t) \leq 0.75\right\}
\end{aligned}
$$

ここで, $N(\tau)$ は集合ての要素数を表す.この指標を健常者 4 名, PD 患者 4 名の随意歩行 3 試行およびテンポ指定歩行 3 試 行それぞれについて求めた結果を図 4 に示す. 図中の各プロ ットは，同一被験者の同一歩行タイプにおける歩行指数の平 均を表す (誤差棒は土1SD). 自由歩行時の歩行指数について, 被験者タイプ(健常者またはPD 患者) と被験者個人の 2 要因で 二元配置分散分析を行った結果, 健常者に対し PD 患者が有意 に小さい歩行指数を示すことがわかった $\left(\mathrm{p}=4.3 \times 10^{-10}\right)$. また 健常者あるいは PD 患者それぞれについて, 歩行タイプ(自由 歩行またはテンポ指定歩行) と被験者個人の 2 要因で二元配 置分散分析を行った結果, 健常者も PD 患者も自由歩行とテン ポ指定歩行で歩行指数に有意差があった（健常者 : p $=0.0047$, PD 患者 : $p=0.041)$. ただし, テンポ指定歩行による歩行改善 効果は健常者と PD 患者で全く逆の傾向を示し, テンポ指定に より健常者が不自然な歩行になるのに対し, PD 患者は歩行が 改善した.

\section{4. 結論と展望}

本研究では, 歩行分析によるPD の重症度評価指標の検討を, まず足圧分布データの圧力中心軌跡を解析することにより行 った. その結果, 圧力中心軌跡から定義した歩行指数によっ て, 健常者と PD 患者を特徴づけられることを示した. また, メトロノームを用いたテンポ指定歩行の歩行改善効果につい て定量的に評価することが可能となった。

今後は足圧分布についてさらに検討を行う一方，同時計測 している筋電データおよびモーションキャプチャーデータの 解析を進め, 歩行障害の程度から重症度を評価する解析手法 を統合的に開発していく予定である。

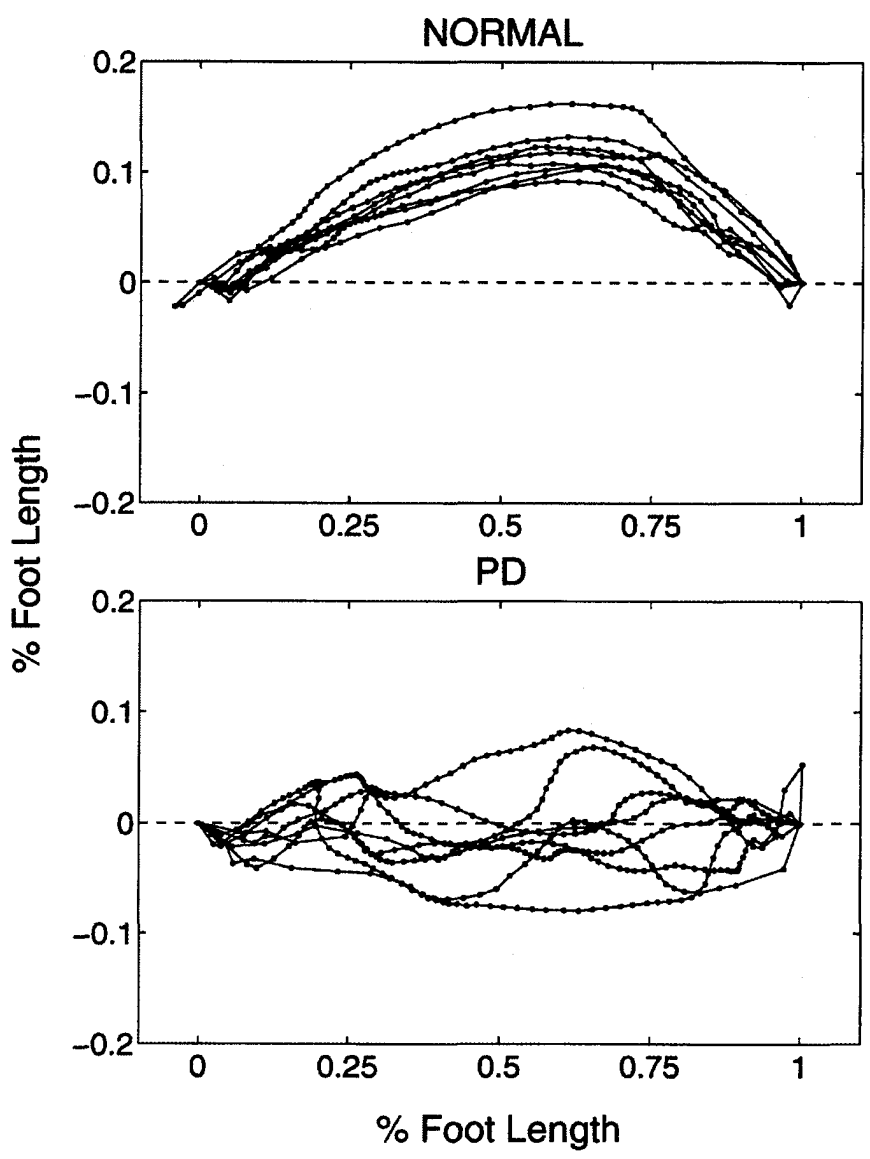

Figure 3 Typical examples of center-of-pressure trajectory for normal controls and PD patients during voluntary gait.

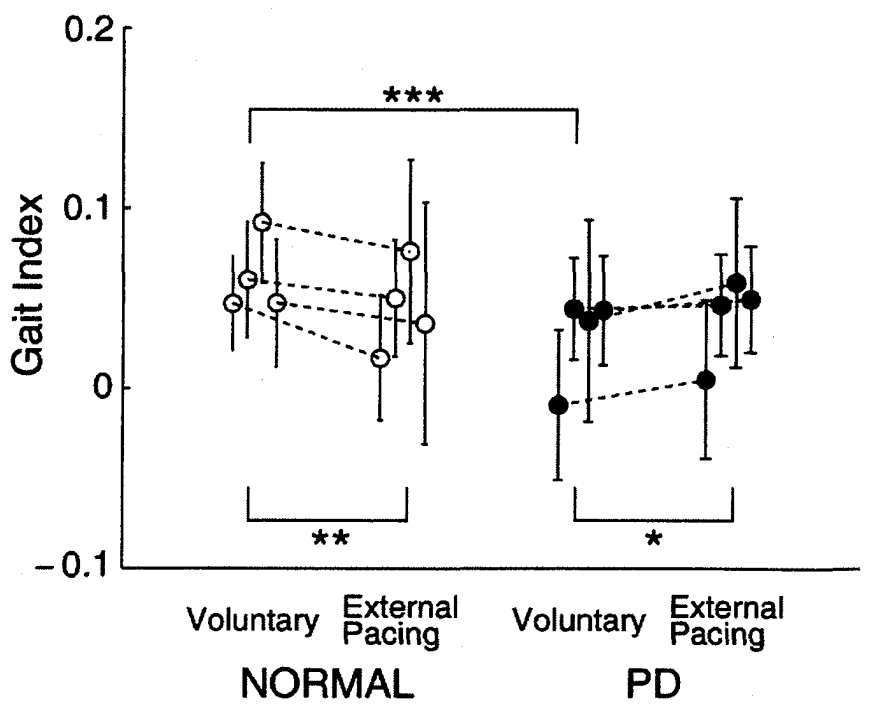

Figure 4 Gait index obtained from the data of center of foot pressure.

\section{謝辞}

本研究の一部は科学研究費補助金 - 基盤研究 (A)（課題 番号 16200005)の援助を得た.

\section{参考文献}

(1) Hoehn M, Yahr M. Neurology 17:427-42, 1967.

(2) Fahn S et al., Recent Developments in Parkinson's Disease 2:153-163, 1987. 